\title{
Late Holocene sediments in the profound abyss of Southern Lake Baikal
}

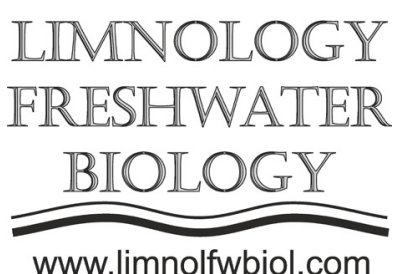

\author{
Vologina E.G. ${ }^{1 *}$, Sturm M. ${ }^{2}$, Vorob'eva S.S. ${ }^{3}$, Budnev N.M. ${ }^{4}$ \\ ${ }^{1}$ Institute of the Earth's Crust, Siberian Branch, Russian Academy of Sciences, Lermontov Str., 128, Irkutsk, 664033, Russia \\ ${ }^{2}$ Swiss Federal Institute of Aquatic Science and Technology, CH-8600 Dubendorf, Switzerland \\ ${ }^{3}$ Limnological Institute, Siberian Branch, Russian Academy of Sciences, Ulanbatorskaya Str., 3, Irkutsk, 664033, Russia \\ ${ }^{4}$ Irkutsk State University, K. Marks Str., 1, Irkutsk, 664003, Russia
}

\begin{abstract}
Here we present new data of bottom sediments, which were collected in March 2018 in the deep water of Southern Baikal. The deposits consist of pelagic mud, intercalated by three turbidites. The uppermost $2 \mathrm{~cm}$ of the core are formed by the light layer of a diatomite, consisting mainly of valves of Synedra acus (up to 219 million cells / g). We attribute the increased content of this diatom species in the upper part of the core to warmer climatic conditions.
\end{abstract}

Keywords: Lake Baikal, sedimentation, pelagic mud, turbidites, magnetic susceptibility, diatoms.

\section{Introduction}

The purpose of the research is to study recent sedimentation in Lake Baikal in a rapidly changing climate. For this undisturbed sediments, accumulated under calm conditions in areas with relatively high sedimentation rates are most suitable. In particular, the surface sediments of the Southern Baikal Basin meet these requirements.

\section{Material and methods}

The core BAIK18-1 (length $59 \mathrm{~cm}$ ) was taken in Southern Baikal offshore the Baikal NEUTRINO Telescope Station (Cape Ivanovsky, $106 \mathrm{KM}$ of the Circum-Baikal Railroad) 5146.076’ N; $104^{\circ} 24.948^{\prime}$ E. The sampling was carried out from the ice at a water depth of $1366 \mathrm{~m}$ with an UWITEC Corer in March 2018. The core was cut, photographed and lithologically described with smear-slide examination. Magnetic susceptibility was measured and diatom analysis was performed within intervals of $1 \mathrm{~cm}$ throughout the core.

\section{Results and discussion}

A light diatomite layer is observed in the uppermost $2 \mathrm{~cm}$ of the core (Fig. 1A). Below this layer an oxidized brown to brown-black layer between 2 and $4.5 \mathrm{~cm}$ is developed at the top of pelagic biogenic terrigenous mud, intercalated by turbidites. This succession is characteristic for deposits of the deep- water basins of Lake Baikal (Vologina and Sturm, 2009; Sturm et al., 2016). Turbidites were found at $18-22.5 \mathrm{~cm}, 35.5-38 \mathrm{~cm}$ and 49-59 cm (Fig. 1A). They are characterized by darker color, coarser grain size, the presence of terrestrial plant debris, an increased admixture of mica particles and an upwards grading texture. The gradation is clearly manifested between 35.5 and $38 \mathrm{~cm}$. The base of the turbidite is formed by sand grading to silt with slight admixtures of clay.

Sedimentation rates of $0.036 \mathrm{~cm} /$ year can be taken from dating results of core BAIK00-1, which was recovered within the immediate vicinity of core BAIK18-1 (Sturm et al., 2016), with the three turbidites deposited during the years $1030 \mathrm{AD}, 1310 \mathrm{AD}$ and 1670 AD.

Magnetic susceptibility (MS) varies along the core BAIK18-1. Minimum values are noted in the uppermost layer of diatomite $\left(-14.8 \cdot 10^{-6} \mathrm{SI}\right.$ units). In pelagic biogenic-terrigenous mud MS does not exceed 56 . $10^{-6} \mathrm{SI}$ units. In turbidite layers, this value is generally increased. Maximum MS is recorded at a depth $38 \mathrm{~cm}$ $\left(148 \cdot 10^{-6}\right.$ SI units) and are confined to the base of the turbidite (Fig. 1A).

The content of microfossils in the core BAIK181 varies greatly (Fig. 1B). Planktonic diatoms dominate with 16.7-307 million valves per gram of dry sediment (mln valves/g). The number of benthic species is $0.24-3.13 \mathrm{mln}$ valves/g, chrysophyte cysts 22.3-61 million specimens per gram of dry sediment (mln specimens $/ g$ ), sponge spicules $0.01-0.32$ $\mathrm{mln}$ specimens $/ \mathrm{g}$ and pollen grains $0.02-0.32 \mathrm{mln}$ specimens/g. The diatom composition is dominated by Aulacoseira baicalensis (Wislouch) Simonsen (0.42-

*Corresponding author.

E-mail address: vologina@crust.irk.ru (E.G. Vologina) 
A

B

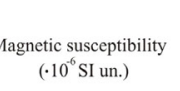

BAIK18-1 -40 $\begin{array}{lllllll}0 & 40 & 80 & 120 & 160\end{array}$
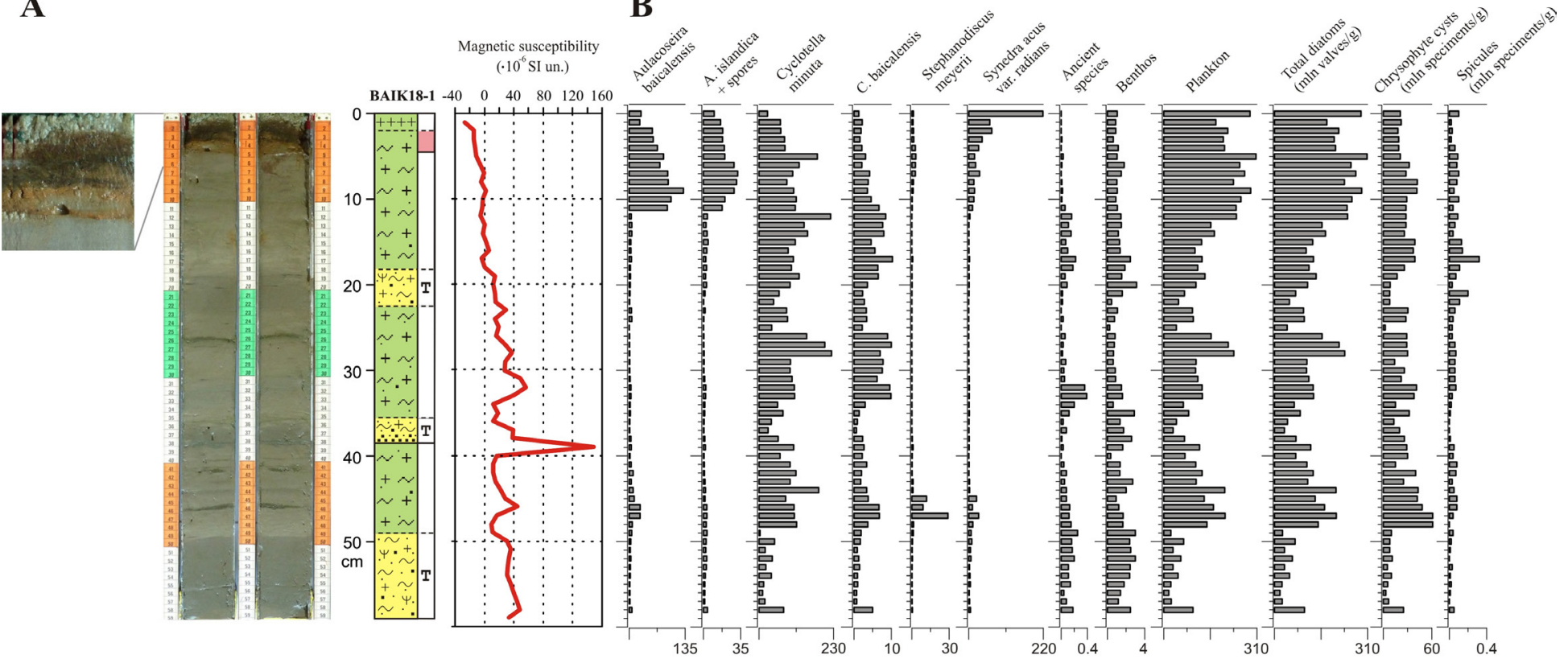

擖喿

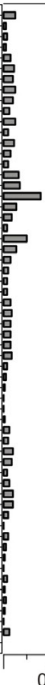

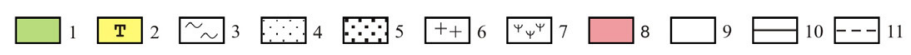

Fig.1. A. Photo, lithology and magnetic susceptibility of core BAIK18-1. Legend of lithology: 1 - pelagic mud; 2 - turbidite; 3 - clay, 4 - silt, 5 - sand, 6 - diatoms, 7 - land plant remains; 8 - oxidized sediment, 9 - $\mathrm{O}_{2}$-reduced sediment; 10 - distinct boundaries between layers, 11 - indistinct boundaries between layers. B. Distribution of diatom assemblages in core BAIK18-1.

$45.13 \%) ;$ A. islandica (O.Müller) Simonsen with spores (0.2-13.4\%); Cyclotella minuta (Skvortzov) Antipova (12.4-95.8\%); Cyclotella baicalensis Skvortzov et Meyer (0.81-7.94 \%); Synedra acus subsp. radians (Kützing) Skabitsch. (0.04-76.02 \%); Stephanodiscus meyeri Genkal et Popovskaya (0.01-14.1 \%). This composition indicates the Late Holocene formation of the studied deposits. Also present are redeposited ancient diatoms (0.01-0.39 $\mathrm{mln}$ valves $/ \mathrm{g})$. They are represented by Stephanodiscus Ehrenberg, Cyclotella (Kützing) Brébisson, Aulacoseira Thwaites, Tertiarius Håkansson et Khursevich, Stephanopsis Khursevich et Fedenya and are characteristic for Pliocene-Pleistocene sediments of Lake Baikal (Kuzmin et al., 2009). Reduced numbers of diatoms and a slight increase of benthic species are observed within turbidite layers (Fig. 1B).

In the uppermost light layer, a peak of Synedra acus was observed (up to $219 \mathrm{mln}$ valves $/ \mathrm{g}$ ). The content of this species of diatoms is still quite large (up to $39 \mathrm{mln}$ valves/g) down to a depth of $3 \mathrm{~cm}$ (Fig. 1B). The dominance of the Synedra in recent sediments can be attributed to warmer climatic conditions during their formation. This conclusion is confirmed by results of a drilling core BDP-96 from the underwater Akademicheskii Ridge of Lake Baikal. There peaks of Synedra are confined to warm isotopic stages (Khursevich et al., 2001). Recently it was established that due to global warming there has been an increase of Synedra and a decrease in endemic species of diatoms in the bottom sediments and within the water column of Southern Baikal (Roberts et al., 2018; Vologina et al., 2019; Bondarenko et al., 2020). Our new data confirm this conclusion.

\section{Conclusions}

The main types of bottom sediments collected at a depth of $1366 \mathrm{~m}$ in the Southern Basin of Lake Baikal are pelagic mud and turbidites. They differ in color, granulometry, magnetic susceptibility, composition of diatoms, etc. The increased content of the diatom species Synedra acus within recent deposits is probably a consequence of global climate warming.

\section{Acknowledgments}

The authors are thankful to T.O. Zelezniakova (Limnological Institute SB RAS) and E.G. Poliakova (Institute of Earth Crust SB RAS) for analytical work. These studies were supported by EAWAG (grant № 85145).

\section{References}

Bondarenko N.A., Vorobyova S.S., Zhuchenko N.A., Golobokova L.P. 2020. Current state of phytoplankton in the littoral area of Lake Baikal, spring 2017. Journal of Great Lakes Research 46: 17-28. https://doi.org/10.1016/j. jglr.2019.10.001

Khursevich G.K., Karabanov E.B., Prokopenko A.A. et al. 2001. Detailed diatom biostratigraphy of Baikal sediments during the Brunhes Chron and climatic factors of species formation. Geologiya i Geofizika 42(1-2): 108-129. (in Russian)

Kuzmin M.I., Khursevich G.K., Prokopenko A.A. et al. 2009. Centric diatoms in Lake Baikal during the Late Cenozoic: morphology, systematics, stratigraphy and stages of development (based on the deep cores of the Baikal Drilling Project). Novosibirsk: Academic Publishers «GEO». (in Russian) 
Roberts S., Swann G.E.A., McGowan S. et al. 2018. Diatom evidence of 20th century ecosystem change in Lake Baikal, Siberia. PLOS ONE 13(12): 1-20. https://doi.org/10.1371/ journal.pone.0208765

Sturm M., Vologina E.G., Vorob'eva S.S. 2016. Holocene and Late Glacial sedimentation near steep slopes in southern Lake Baikal. Journal of Limnology 75(1): 24-35. DOI: 10.4081/jlimnol.2015.1219

Vologina E.G., Sturm M. Types of Holocene deposits and regional pattern of sedimentation in Lake Baikal. 2009. Geologiya i Geofizika 50(8): 933-940. (in Russian) http:// www.izdatgeo.ru

Vologina E.G., Sturm M., Budnev N.M. 2019. The results of experiments with sediment traps in South Baikal from March 2013 to March 2015. In: XXIII International Scientific Conference (School) on marine geology "Geology of the seas and oceans", pp. 20-24. 